symptoms. The graduated bath from $100^{\circ}$ to $70^{\circ}$ was given, and it was used with the greatest care. I shall never forget the shivering and exhaustion that followed its use. Dr. Coupland refers to the "calm sleep" that ensues from it. This patient, after the second bath, fell into a sleep from which he never awoke. He became comatose, pulmonary congestion supervened, and he died a few days after. This case made a very deep impression on me, and with the recollection of it before my mind, and holding the foregoingr views, I regard the cold bath treatment of typhoid fever as bad practice and fraught with the most dangerous consequences. I am, Sir, yours obediently,

W. M. Collins, M.D.,

Cadogan-place, S.W., March, 1884. Surgeon, Royal Horse Guards.

\section{FOR URETHRAL MALADIES.}

\section{To the Editor of THE LANCET.}

SIR,-Will you do me the favour to give space to the following formula for an injection which I find of great service in cases of urethral trouble known by the several terms ending in -rhoa? These affections are common, underlying causes of "mind-worry" and "nervousness." When other remedies have failed, I find this injection, used twice a day with one of Squire's convenient and safe syringes, puts an end very speedily to the local inflammation and its consequences. It is possible it may be useful in other cases of analogous pathology. The only difficulty is to get the injection well prepared. I therefore write the prescription thus :-

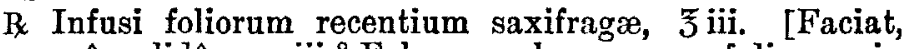
ex aquâ calidâ, xcviii. ${ }^{\circ}$ Fahr., per horas sex; foliorum i., aquæ x.] Glycerini, $\tilde{\jmath}$ i. Misce. Fiat injectionem, ut bis die utendum. I am, Sir, yours faithfully,

Welbeck-street, Carendish-square, W. J. MoRTIMER-Granville.

\section{"A SOCIETY OF MEDICAL OFFICERS OF SCHOOLS."}

To the Editor of THE LANCET.

Sin,-When I suggested to Dr. Alder Smith, some five years ago, the formation of a Society of the medical attendants at our public schools, you were good enough to offer, on my making a similar suggestion to you, the use of a room at THE LANCEn Office for the first meeting. If this offer could be renewed, it would, I think, further the very desirable object. I am, Sir, yours faithfully,

Wokingham, March 4th, 1884.

J. G. BARFORD.

* * We shall be happy to assist in any way in our power in the furtherance of the object above-mentioned.-ED, L.

\section{THE SUPPLY OF WATER BY METER.}

\section{To the Edetor of THE LANCET.}

SIR,-I have noticed with regret the proposition which is to be submitted to Parliament by the Corporation of London to supply water by meter. Surely, if such an unfortunate and retrograde step were taken, the underground cesspools which exist in London in the form of foul house drains, to the extent in the whole metropolis of four thousand miles at least, would be still more choked with human excreta, and an alarming increase of zymotic diseases must be anticipated. I have recently examined a soil-pipe (six-inch) from a watercloset which was vertically placed, and even that pipe contained a large accumulation of foul matter; and there can be no doubt whatever that any diminution in the flushing of the house drains in a great city like the metropolis would be attended with serious injury to the public health, and should be viewed with great alarm.

I am, Sir, yours obediently,

Birmingham, March 3rd, 1884. $\quad$ E. CHESSHIRE, F.R.C.S.

\section{N E W C A S T L E - O N - T Y N E. (From our own Correspondent.)}

NORTHERN COUNTIES HOSPITAL FOR DISEASES OF THE CHEST.

THE annual meeting of this institution, which seems to be growing in usefulness and public favour, was recently held. The report showed that the financial position was good, and the committee had decided upon reducing the price of their letters, giving six for each subscription of one guinea. The operations of the charity had been hampered for want of suitable space, but a difficulty still presented itself of finding suitable premises for the hospital. At the same meeting Dr. Wm. Murray was appointed consulting physician.

NEWCASTLE DISPENSARY.

The annual meeting of this charity has also been held During the year the governors have received in legacies the sum of about $\mathcal{E} 7000$, and from the Hospital Sunday Fund over $£ 400$; and the committee have been enabled to invest $£ 11,000$ during the year. The number of patients treated had been over 7000 . The casual patients had contributed $£ 117$, being at the rate of twopence each, but anyone acquainted with the class of patients attending the dispensary will doubt that this paltry sum by any means represents what the patients might pay had the contributions been in fair proportion to their means. The dispensary has now \& large amount of invested capital and a good subscription list, and it is felt that it might very properly and with great advantage employ a portion of its funds in estab. lishing a country sanatorium or convalescent home for some of its many patients, and thus relieve the pressure on the Prudboe Home at Whitley. It is often pointed out that during a very considerable portion of the year this excellent seaside institntion is not at all suitable for a variety of chest and other cases.

\section{NEWCASTLE CHILDREN'S HOSPITAL.}

The annual meeting was held a few days ago at the Children's Hospital, under the presidency of Sir W. G. Arm. strong. The hospital during the past year had received some handsome sums in legacies, but the ordinary expenditure had exceeded the regular income for the past two years. The want of a convalescent home for the children was referred to in the report, but the committee expressed the opinion that the present state of the finances of the hospital rendered it inexpedient to enlarge the expenditure. What the Children's Hospital is, however, now unable to do in the way of establishing a convalescent home at present might very well be done in co-operation with other institutionsthe Dispensary, for instance, with its abundant and growing funds. Some mode should be promptly adopted, if only as a measure of justice to the medical staff, by which the little convalescents might be carried from the present dingy building into light and air.

\section{SUNDERLAND HOSPITAL SUNDAY.}

The annual Sunday Hospital Collection has been taken in Sunderland, but so far there is a visible decline as compared with last year, and this, it is to be feared, is significant of the depression which has set in in the shipbuilding trade and several of the industries of the town.

Newcastle-on-Tyne, Feb. 27th, 1884.

\section{IRELAND.}

\section{(From our own Correspondent.)}

TIIE MEDICAL ACTS AMENDMENT BILL,

A DEPUTATION consisting of seven members of Couneil of the Royal College of Surgeons had an interview on Monday last with his Excellency the Lord-Lieutenant, to bring under his notice the views of the College in reference to the Medical Bill. They stated that they came to commur nicate certain resolutions passed at a recent special meeting of the College in reference to the proposed legislation. The first resolution was to the effect that they were desirous to aid in the accomplishment of such reforms as have been found to be necessary, and wished to maintain the rights and privileges of a College which they considered would be unnecessarily and unjustly interfered with by the proposed Bill. The Bill proposed to establish Divisional Boards, which would supersede the present institutions in all their most important functions, and thereby reduce them to a state of uselessness and poverty. They therefore prayed his Excellency to use his influence to have the matter reconsidered before the Bill was proceeded with. The Lord-Lientenant in his reply, said that Lord Carlingford was most anxious to press forward the measure, and probably there might be a 